\title{
The War's Effect On Merchant Shipbuilding-I.
}

\author{
The Standard Ship and Momentous Problems of Production
}

By Homer L. Ferguson

IN a military sense, this war is narrewed døwn to the question as to whether the German submarines can sink the English ships and thøse of the Allies at such a rate as to force peace upon Great Britain, $\bullet$ urselves and the other Allies before the Germans are sufficiently the •ther Allies before the Germans are sufficiently
thrashed on land to recønize that fact. When the subthrashed on land to reconize that fact. When the sub-
marine campaign was started in February, the German Minister of the Navy promised his peøple that in August of this year England wøuld be brøught t• her knees. The rate of sinking for a time increased until it became probably three or four times the rate of building.

There have been tw $\bullet$ schøols of thought regarding the proper method of meeting the German submarine campaign. One schøol has held that only by the production of the maximum number of ships in the shortest duction of the maximum number of ships in the shortest
space of time until the production of new vessels shøuld more than equal the destruction of vessels in being, would the question be answered. The other school has held that there were vessels in plenty to feed England and

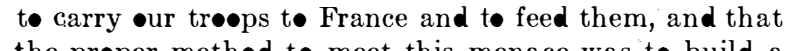

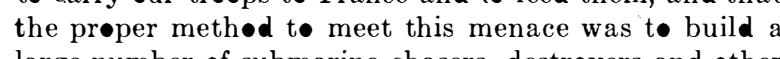
large number of submarine chasers, destrøyers and other vessels $\bullet$ war tø $g \bullet$ after the submarine itself. There is
a very strong feeling that catching the submarine away frøm its base is sømething like catching bees •ut amøng the flowers instead of in the hive.

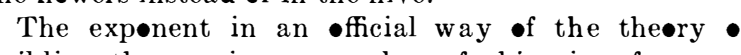
building the maximum number of ships is, of course, the United States Shipping Board, with the Emergency Fleet Corporation as the largest individual •wner and or at any other time in the history of the world. Al of the shipbuilders have had their new ships comman-

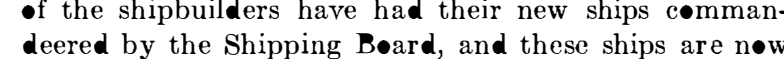

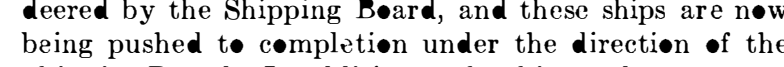
Shipping B॰ard. In addition tø the ships under construction at the time the Shipping Board took •ver all these vessels on August 3d last, the Shipping B॰ard has placed contracts for 200 to 300 additional steel ships and for have built ships at a very rapid rate during the past six mønths but prier to that time their capacity had fallen of wøefully. The figures of British shipbuilders are that in nørmal years their capacity in tons was abøut twe normal years their capacity in tøns was abøut twe
million. In 1915 they built $\bullet$ nly 700,000 tøns. In 1916 million. In 1915 they built $\bullet$ nly 700,000 tons. In 1916
only 550,000 tøns. In the first six mønths $\bullet 1917$ they built 500,000 and by the end of 1917 they will have buil

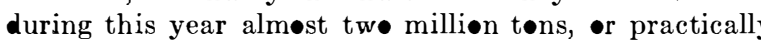
their normal tonnage.

In comparisøn, it is interesting to løok at $\bullet$ ur record which is mostly in tha future. The largest tonnage eve built by us in any year prior to the present year was in 1908, when we built 615,000 tons. In 1917, or at the
end of the fiscal year of $1916-17$, on July 1 st, the total tonnage turned out in merchant ships in this country was close t• 800,000 tons. Of cøurse we expect that that will be bettered very much, and the production, excep for labor difficulties, would have been very much greater than that; but it is a far cry frøm 800,000 or $1,000,000$

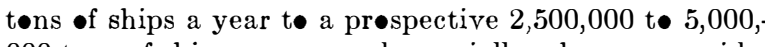
000 tøns $\bullet$ ships a year, and especially when we consider that the best the first shipbuilding country of the world

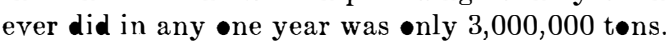

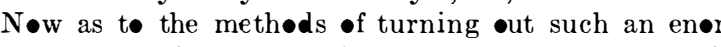
mous tonnage in a short time. The standardized shi was first thought of by N॰ah. It certainly would have been had he built a second ark. Every •ther shipbuilde has thøught what a jøyful thing it would be if he could -nly build tw॰ or three or four ships just alike. If th war does nothing else for shipbuilding, it will at least demonstrate that the individual tastes of individual - wners need not be met in every instance. Ship are nøt built alike før the reasøn that ships are built by units and tens instead of by thousands. And what ap-

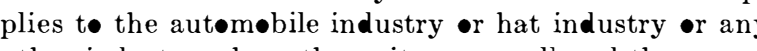
-ther industry where the units are small and the aggregate number is very large is r.t possible where you are building a thing that is worth a half million or a million $\bullet$

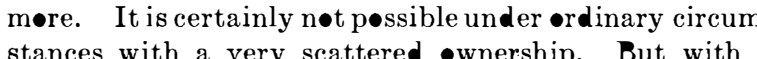
single $\bullet$ wnership, like the Emergency Fleet Corp॰ration it becomes pøssible for the •wner t॰ specify that al

${ }^{1}$ President of the Newport News Shipbuilding and Dry Dock Company.

Abstract trom an address delivered at a Joint Meeting of the American Society of Mechanical Engineers. Published in the American society of Mechanical Engineers.
Journal of the Engineers' Club of Philadelphia. ships shall be alike, and thus we have standard ships! There is an idea extant that if a ship is called "fabricated" or "standardized" it becomes rather easy to build.

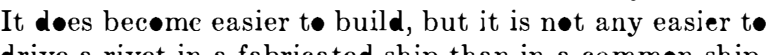
drive a rivet in a fabicated shp than in acomy and the 7,500-ton fabricated ship will have abøut 650,000 rivets and søme riveters must d• a considerable amøunt of work to drive those rivets in that ship the same as

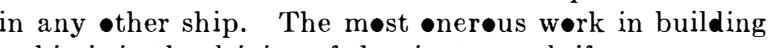
a ship is in the driving of the rivets; and, if any concern is gøing t• build •ne ship a week, it must drive 650,000 rivets a week. When we consider that the best rivet drive is by the Union Iron Works, where they drive 250,000
rivets a week, and the next best by the three largest shiprivets a week, and the next best by the three largest shipthe prøblem of driving 650,000 rivets a week assumes a rather difficult aspect tø the casual $\bullet$ bserver. Still, we all hope it will be done, but if it is done it means the importation of an en॰rmøus number of new workers into the industry.

The fabricated ship has the center of the stage at the present time. In England a standardized ship was adopted which is very much like a fabricated ship, and they are being turned out at a rapid rate. The first ships have already been completed and are on the sea n॰w, if indeed thay have not already arrived in this country. The fabricated ship, like the English standard ship, has the disadvantage of low speed, and at the same time it has the advantage of a large carrying capacity. The records of submarine sinkings, such as have been gathered, indicate that speed is probably the safest defense against the submarine. The number of very slow ships great in proportion to the number attacked. Prøbably 90 per cent of the slow ships are sunk when attacked by a submarine. As the speed becomes greater the immunity of the ship from torpedo attack becomes greater-n॰t -nly because she presents a more difficult target but also because the vessel may run away from the submarine in darkness or in daylight if she has a greater speed than the submarine has on the surface, and alse because the vessel may be maneuvered much more quickly. One of the most gratifying things about submarine warfare is that the torpedoes are not making the speed as in the early days of the war. The speed of the torpedo has undoubtedly become much decreased. Just why we do

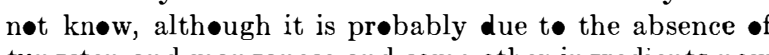

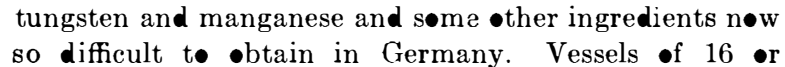
17 knots have actually dodged the torpedoes.

The vessel of 16 or 17 knots is alsø needed to carry soldiers. We are shipping all •ur soldiers to Eurøpe in vessels of $14 \mathrm{kn} \bullet \mathrm{ts}$ or over because it is thought to be tøo hazard ous tø ship them in the slower vessels. W have at the present time in this country enough vessels

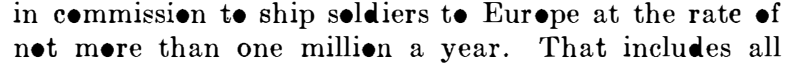
vessels $\bullet 14$ kn॰ts $\bullet$ • $\bullet$ ver. But by building a large ship as well as a speedy ship an additional factor of safety is -btained, which may be illustrated by stating that a torped• will blow just as big a hole in a little ship as a big ship. When a small, short ship has a large hole in it a relatively larger proportion of its length is $\bullet$ pen to the sea. When a similar høle is bløwn into a long ship a very much smaller prøportion of that vessel is $\bullet$ pen to the sea. So

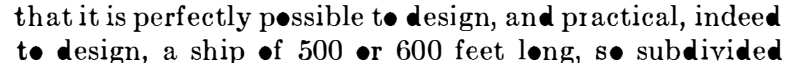

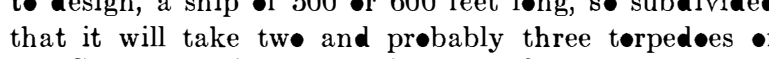
the German variety and still stay afloat. The design, høwever, must be of such character that when the cømpartments are flooded the ship will still remain upright.

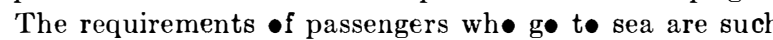
that the ordinary passenger ship shall have a very small metacentric height. But with a small metacentric height the rolling of the vessel is very easy, sø that the

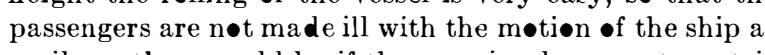
easily as they would be if there were a large metacentric height and the ship rolled quickly and with a jerk. Th -rdinary passenger ship is modeled with a small meta-

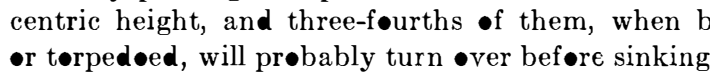

A great deal of talk was heard years age, when the "Titanic" went down, about making ships safe. The "Titanic" was prøbably the safest ship that ever crøssed he •cean, with the exception of the "Olympic." The "Empress •f Ireland," the "Lusitania" and the whole host of passenger ships of which we have any record have

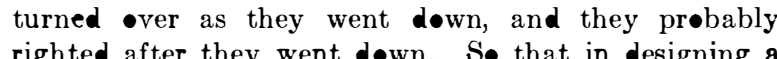
righted after they went down. S• that in designing a ship that will be safe against submarine attack n॰t only must the question of subdivision be taken care of sø a - limit the length of the vessel that may be damaged by remain upright and be able t॰ get int• pørt. A number of vissels have been tornedocd and have been towed into port and repaired on the other side, even after the crews had deserted them. In fact there is a strøng n॰tion that the crews have been •ver-ready t• desert the ships and have left when the ships were still afloat, which is prøven by the fact that these ships have been towed in.

The larger type of ship which will probably be built before the war is $\bullet$ ver by a number $\bullet$ concerns in a position to undertake this work will be designed with a high peed for trøop transpert, with a close subdivision to make the ship safe, and with a large amount of stability - that the vessel will alsø be safe against turning •ver The war sø far has developed, or called attention te, three distinct types of vessels: The standardized or fabricated ship like both the English and the United State have adopted, the large troøp transport which has bo

In addition to these three types of ships brøught $\bullet$ ut by the war, there has been a very definite attempt t• rejuvenate what some of us have considered a dead industry. I d n not kn॰w whether there are many wooden ships building arøund Philadelphia or n॰t, and I would not like t• criticise the wøoden ship builders; but I shøuld like t• see a few. We have a few of the •lder wooden ship

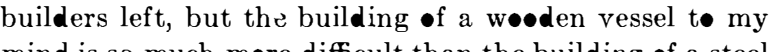
mind is so much more difficult than the building of a steel vessel and requires se much higher skill than does the building of a steel vessel that I wonder how they can ever expect to build them

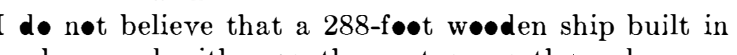

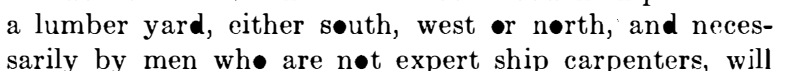

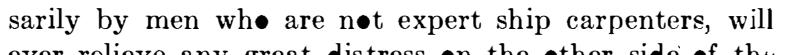
ever relieve any great distress on the other side of the hand, caused by lack of fuel or food. On the other h॰me. My chief regret is that they are n॰t made sh॰rter, because when such ships are $\bullet$ ver $200 \mathrm{ft}$. løng it is rather difficult to høld the ends up. If we get more vessels through building wøoden ships, let us build them, but it is unfortunate that the type was settled before many prøfessional wøoden ship builders were $\bullet$ the jøb. The wooden ship builders of course have taken a good many men frøm the steel shipyards and have lessened production t॰ just that extent; but, on the $\bullet$ ther hand, they will add a very considerable tonnage, nøw that practically all -ur large cøastwise ships are either gøing abrøad or are in the way of being commandeered for foreign service, s that the wøoden ship will serve a useful purpøse.

The standard ship prøbably •ffers the best •pportunity for a large increase in $\bullet$ ur tønnage. The standard ship has been built $\bullet$ the Great Lakes for years. Shipbuilding there has bec $\bullet$ largely a manufacturing $\bullet$ peration for the reason that the ships themselves simply form a part $\bullet$ the manufacturer's business of carrying ir $\bullet$ ore from Lake Superior down through the Canal to the eastern points where it is shipped to the steel furnaces. ardization of docks, hatches and sø $\bullet$, and the methød of construction became standardized because the work which the ship did was standardized. Many ask why we do not build ships just like they do on the Lakes, and the

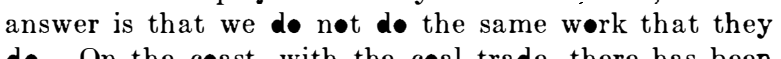
do. On the coast, with the coal trade, there has been ized ship the main benefit is not in the hull of the vessel, or in the fabrication of the vessel in the steel mill. The main benefit is that the machinery and the outfit, the winches, the pumps, the steering gear, the engines and

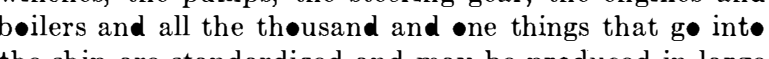
the ship are standardized and may be produced in large quantities at some point other than the yard of the builder. The standardization of the fittings of a vessel are more important t• my mind than the standardization
of the hull. The amount $\bullet$ money saved in the latter will be the money to build the templets, patterns, etc., amounting to not more than $121 / 2$ to 15 per cent of the labor cost of the hull. We are tøld, tøe, that all the riveting will be done at the steel mills. It prøbably will not and if 20 per cent is done it will be more than I think will be done unless the railroar!s will carry pieces of steel as large as this auditorium.

Shipyards have naturally tried to standardize within

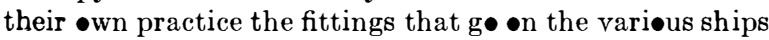


they build, and a great step is being made in that direction by one of the largest corporations in the country. The Bethlehem Company own so many shipyards that the are in a position to standardize as between their variou yards, with the result that there will be considerable saving in cost and in time in the production of all the things that go into a ship. But in building the standardthings that go into a ship. But in building the standard-
ized ship, or in building any other ship, the real problem is not the problem of equipment; it is not the problem of money even; it is not, except in part, the problem location, but it is the problem of men. A very simple lesson in arithmetic will indicate that if 100,000 rivets are to be driven in one day and any one gang of riveter will drive 300 , then it will take so many men and boys and helpers to get that drive. It is quite desirable to get
back to our arithmetic again when we have built so many back to our arithmetic again when we have built so many ambitious high hopes of what we expect to do. I can
state for our company, the most fortunate thing we did when this war started was that we only promised to deliver ships in the quantity that we had been delivering before. In other words, we did not capitalize our noble purposes and high ambitions, and I am very happy to say that we therefore have only about four more veus on our hands for which we recieved a fixed price.

Saying that we are going to do a thing does not do it and hoping that we are does not do it, and promising to the newspapers that we are going to build all these ships does not do it. As a matter of fact, enthusiasm and high hopes, unless counterbalanced by good judgment and ex perience, do more harm than good, because a good many people are lured into a sense of security that we are going to win against this submarine menace, when, as a matter of fact, there is nothing to ju-tify any such conclusion. For instance, on the Delaware and on the Chesapeake, which we, on the Chesapeake, are plewsed to conpeake, which we, on the Chesapeake, are plested to con-
sider the two largest shipbuilding communities in the Cnited States, there are at present about $33,000 \mathrm{men} \mathrm{em}$ ployed in the shipvards. There could be cmployed to advantage in these same yards at this time a total of 48,000 men. and within the next six months, or the next nine months at the latest, these same yards, harring the fabricated shipyards, could employ to advantage a totil of $60,000 \mathrm{men}$. So the problem becomes arithmetical again. You have 32,000 men working. To get the maximum preduction out of the shipyards allendy in existene you will need to use 60,000 men. Where are the 28.000 extra trained shiphuilders to come from? Add to that the fabricated shipyards, which on the Delaware will probably requir, $20,000 \mathrm{men}$, and in the vicinity of $\mathrm{New}$ York an extra 10,000, and we have in this immediate dis the shipbuilding businas.

According to Admiral Capps, there will be needed in the whole United states in shipbuilding within the next six months an additional 150,000 men. Now, conside for a minute where these men must come from or how we are to get them. In the firt place, most shipbuitling men
or mechanics require both skill and ixperience. We ean or mechanies require both skill and ixperience. We can
give them the experienee fairly quickly, but we have not time to give them the skill. In other words, it is necessary that men be eceruited from industries where they do work similar to the work of shipbuilding in order that they may become quickly adapted to the work of shipbuilding. I say other industries without specifying what building. I say other industries without specifying what
particular industry. Of course, it would be natural to particular industry. Of course, it would be natural to
pick the non-essential industries if there are any such pick the non-essential industries if there are any such other industry if necessary, because our problem in th war becomes the most difficult when the question of transportation is considered.

We are operating or preparing to operate 3,000$)$ mile from our base and that is the crux of the whole question. A reasonable solution has been proposed for every physiA reasonable solution has been proposed for every physilem of over-sea transportation. I do not know whether it is giving away information that would be of benefi to the enemy to say that that transportation is entirel inadequate, but if anyone does not think so all he has to do is to look at the congestion in our various ports. The problem of over-sea transportation absolutely has to be met before we can get into the war effectively, and the problem of sea transportation is probably the most dificult of all problems we have to face. Therefore, the men cult of all problems we have to face. Therefore, the men
should be furnished for the solution of this problem, no should be furnished for the solution of this problem, no
matter what industry they are taken out of. We are making a fine, large army; we are making all kinds of quartermaster supplies and guns and other things, but none of them are of any use whatever unless carried to not only that, but the moldicrs that are carried to Europe must be fed and must have arumunition. The excito ment ereated by the war so fur will be but a gentle zephyr compared to the excitement that would permeate the United states if, perehance, we get a million men in France from the United States and they go hungry.
My own opinion as a plain American is that that is the largest problem that looms up in the fut ure. The distress that has been oceasioned here by the suffering. of Frenchmen, Englishmen and Brlgians and the different peoples of Lurope will be very slight esmpared with what will be occasioned by some of our boys not hilving the roper blankets or foods or something else, all of whic must be carried to them in ships. So that the problem
of building these ships becomes a military problem of of building these ships becomes a military problem of
prime importance-the most important single problem hat confronts us at the present time.

I have been quoted recently in an extract that I gave of this talk to the newspapers as favoring the conscription of laboring men. I do not say that I favor the conseripthon laboring men, but I do say this - that sooner o ater the United states will tell all men who are essential the war that this is their job and they are to stay by it until the war is over. It is perfectly ridiculous that ou men who are already in Europe and those who are going there now sheuld for a minute suffer on account of some difficulties that arise between employers and employees in the great shipyards of this country. Not only should the man who pounds iron and driver rivets be told that he shall be kept on his job), but also crory employee in the company, from the president down to the office boy, is to do the same thing, and he is not to seek or obtain other employment, exeept for good reason given the Government authorities. It simply comes down to this Whether we are plitying a game of amusing ourselves or
whether we are in to win. If we are in the war to win, no ene sheuld be timid about telling the laboring man or the unions or anybody representing them just what part they have got to play along with the part that of her people should also play. In fact, when the war started a
faw of us in conversiation with the sorretary of the Navy told him that we thought the thing for him to do was to commindere the shipyards tegether with all their em ployees; to put us all on the (iovernment patyrell if he winted to do so, and give us as many stripes on our uniform as he themght propere and if we did not do as martial us and send us down to Atlanta or some other eonvenient penitentiary. And I think : something of that sort should be done. Any man who has charge of shipsort should be done. Any matn who has eharge of ship)-
building or (nnginecring in any (aipacity who iss not perfectly willing that that should be done both to himself personally as well as to his men has a very one-sided view of this war which needs to be corrected. (Of course,
it is held by the National Council of Defense, and by a it is held by the National Council of Defense, and by a number of exalted bodies that the slatus quo as between this war. Of course, it should remain the sime, and we all know that it is not remaining the same, and we all know that the labor leader's its a rule itre unable to control the men

There is a solution of this labor problem effected with the transport worke.. on the other side; Liverpool, for instance. A number of the soldiers were sent back to
Liverpool and went to work. You will remember a few vears ago in France a great threatened strike on the rail roads was settled by making soldiers out of all railroad (mplover... Our present stevedore troubliss are in a fair way of being settled by giving the colored man a chance $t o$ be a stevedore instead of being a soldier in the trenches and so far as I have been able to observe in our neighborhood, several thousind of them are glad to take advantage of this glorious opportunity and are stevedor-
ing for their country very quietly and very effectively, ing for their country very quietly and very effectively, and I do not see why of all the men who have been passed essential an industry as shipbuilding those of them who are mechanics on conditions set by the Government and on pay to be approved by the Government, to work in on pay to be approved by the Government, to work perchance prefer to go to the front instead of staying in the shipyards

$$
\text { [To be CONCluded] }
$$

\section{A Nomenclature of Smells}

A CORRESPONDENT asks, "Is there no genius prepared to give us a nomenclature of smells?" and, referring to a pilper on "Wound Treatment" in our columns, suggest that it ought to be possible to name a wound smell, and so to obviate the despateh of samples. An approach has been made miny times, but with little suecess, to the establishment of a system of nomenclature comparable for smells with the classification which we have been able to set up in the cases of the senses of seeing and hearing. The fact is that, so far, smells have not been capable of the allilysis which is possible with light and soment. In both these cases we have a gamut or a law of octaves, a
also with the atomic weights in chemistry, and perhaps some day a similar analysis in regard to odours will be some day a similar analysis in regard to odour's will be
forthcoming. It present we are without a nomen- clature, and everybody experiences the difficulty of ( We have to be content to say that a familiar. The fact is that the sense of smell has been the least cultivated of the senses, and it is just possible that if the subject had received the same attention as have the senses of hearing and sight the study of odors would have reached a higher scientific plane, though, it appears to us, the classification of smells must always suffer from the absence of the mathematical analysis capable in optics and acoustics. As it is, in our struggle to describe a smell we are confined to using such terms as peculiar, persistent, forth. Now these are all adjectives which give us little ( of an object called red, and when we fall back on the reference to common objects, for the purpose of more exactly defining a color-thus a yellow color is frequently lescriberd as lemon or canary, a red color as brick or claret-our comparisons are made to objects whose hues are fixed by mathematical laws. In the case of sound and light we have a comparatively narrow scale. There are seven primaries as seen in the spectrum and in the range of notes from $A$ to $G$. It is difficult at present to determine whether smells may be similirly brought into a system of scales or octaves. Such a system, however, has been suggested in the construction of perfumes. Many years ago Dr. Septimus Piesse, for example, set out a series of odors in parallel with a musical scale and showed how it was possible to make a bouquet correspond to a cord. Perfumers thus speak of a gamut of odters, placing the name of the odor in a position correponding to its effect upon the olfactory sense in the order of the amplitude of vibration. The gamuts of odors thus constructed certainly suggests a law of octaves, for we find that, according to Dr. Piesse's ingenious arrangement, at the lower end of the scale the note $\mathbf{B}$ correspond with clove, while the octave $B$ above gives stocks and pinks and the higher octave B cinnamon. The keen sense of smell will recognize a similarity of odors here just us the muscian recognizes the repetition of a note in colors with smells, and thit others speak of certain musical notes as suggesting corresponding colors, is interesting sentimentally but not scientifically. -The interesting

\section{Structure of Hide and Leather Fibres}

$\mathrm{E}_{\Lambda \mathrm{CH}}$ hide fibre consists of a great number of fibril complexes, each complex containing an undetermined number of fibrils, between which gelatin is found in swollen hide. During swelling and falling, the fibrils and their complexes undergo alterations of position, etc. including twisting, the fibrils of fallen hide however being st rairht. The interfibrally penetration of alkali during swelling is easily recognized with the ultramicroscopic. Chrome, aldehyde, and chamois leather show a closer structure of fibres than vegetable-tanned leathers, and are naturally less easily acted upon by boiling with water. While the unswollen hide fibre i more or less optically empty, the leather fibre shows a distinct ultra-microscopic structure, which with vegetable-tanned leather gives information as to the subdivision and amount of tannin taken up, and which can be brought into relation with the physical properties of the leather. The fibrillary structure of gelatin is proved by the ultra-microscope to be a network.-Note in J•ur. Sec. Chem. Ind. in an article by W. MöLler in Z. angew. Chem.

\section{A Gun the Italians Lost}

G ERML interesting photographs have appeared in the pages of the Suppliziner illustrating the sensational engineering feats performed by the Italian army in the prosecution of its campaign on the Austrian border, and on the first page of this issue will be found another view showing a powerful field howitzer being hoisted by derricks and tackle to a snowy mountain top. Hundreds of guns, both big and small, were thus laboriously installed in almost inaccessible mountain fastnesses, but unfortunately, as was developed during the recent calamitous reverses, it was impossible to quickly withdraw the armament thus so advantageoulsy placed. All of these wonderful strongholds among the mountain peaks had to be abandoned when the Italian line was flanked by the Germans, together with their equipment and munitions, and undoubtedly the loss of so many guns is one of the most serious aspects of the catastrophe, for It aly was none too well supplied with guns, and much time will be required to replace them. It was this shortage of guns also that can account for the difficulties encountered in making a quick and successful stand against the advance of the enemy, after the first retreat. 